\title{
Cross-Channel Marriage and Royal Succession in the Age of Charles the Simple and Athelstan (c. 916-936)
}

\author{
Simon MacLean*
}

This article discusses the marriages of four Anglo-Saxon princesses to Continental kings and princes between the years 917 and 930. These are often interpreted as acts of diplomacy, sealing alliances across the Channel and indicating the dominant position of King Athelstan in early tenth-century Europe. I reinterpret the motivations of the princes by reading the marriages as acts of symbolic communication driven by the uncertainty over the West Frankish royal succession in the 920 s and framed by a competition to access a version of Carolingian dynastic legitimacy. This in turn allows us to reflect on the decay of the Carolingian Empire after 888. Because Carolingian-ness was no longer a hegemonic political discourse, I argue that these events belong emphatically to a post-imperial political landscape.

Keywords: Carolingian Empire; marriage; Anglo-Saxon England; Edward the Elder; Athelstan; Charles the Simple; Ottonians; succession; political history; Flodoard of Rheims.

The theme of this issue, decaying empires, is a difficult one to tackle because it is so hard to define what an empire is in the first place. This is certainly true of the ninth-century Frankish Empire of the Carolingian dynasty and its successor in what would become Germany, both of which are customarily included in surveys of historical empires. ${ }^{1} \mathrm{~A}$ vocabulary-based definition is unsatisfactory because the contemporary terms imperium ‘ and regnum ‘ are too flexible to be diagnostic. ${ }^{2}$ Nor can we simply assume that there was an empire when there was an emperor: when Charlemagne (d. 814) revived the imperial title in 800 he had already completed most of his imperialist expanding, while his great grandson Louis II (d. 875) enjoyed imperial status despite ruling only Italy and holding no superior power over the kings in other Frankish realms. A structural centre-periphery analysis is also problematic in that the political heartlands of the empire moved around as successive generations of rulers passed. Alemannia, for example, a peripheral area only fully incorporated into Frankish structures in the early ninth century and rarely visited by any ruler for decades afterwards, suddenly became an imperial centre under the late-ninth century emperor Charles III the Fat (d. 888) who had grown up there. And even tracing the hallmarks of Carolingian political order - its legal categories and social practices - might only get us so far, for it has been argued that, paradoxically, they were reified rather than erased in the years after the empire formally ceased to exist. ${ }^{3}$ In other words, the specifics of the period illustrate the well-known difficulty of developing anything more than the most general taxonomy of empire as a historical phenomenon.

\footnotetext{
* Correspondence details: Simon MacLean, School of History, University of St. Andrews, 71 South Street, KY16 9QW, UK, email: sm89@st-andrews.ac.uk.

1 Burbank and Cooper, Empires in World History, 80-90.

2 Reynolds, Empires.

3 West, Reframing the Feudal Revolution.
} 
A more useful definition of the Carolingian Empire lies in the ruling dynasty itself. As Stuart Airlie has persuasively argued, the main driver of Carolingian politics was the ruling family's constant effort to define themselves as the exclusive and natural rulers of the Frankish realms, and to perpetuate the idea that only male-line members of the family could be regarded as legitimate rulers - an endeavour in which they were largely successful. One advantage of this definition is that it substantiates the case for 888 as the key year in the empire's disintegration - a year in which the death of Charles the Fat brought on a succession crisis which marked the end of the dynasty's monopoly on legitimate royal power. ${ }^{4}$ But this is only a starting point for any discussion of when the empire's decline began. Where Airlie persuasively emphasises the revolt of Boso of Vienne in 879 as a key moment in the undermining of the family's hegemony, conventional accounts of the downturn begin much earlier with the death of Charlemagne in 814, the deposition of Louis the Pious in 833, or the territorial division made at Verdun in $843 .{ }^{5}$ The validity of these older narratives has been challenged by specialists but remains very much alive in broader historical discourse, as seen in Niall Ferguson's evocation of a chaotic sdark age brought about by conflicts between Charlemagne's heirs in the later ninth century, which he presents as a dire warning to those who might wish for a weakening of American simperiak power in the early twenty-first century. ${ }^{6}$

The present article does not enter such debates directly, but uses them to help think through some of the key events at the other end of the story as the Carolingian Empire unravelled in the decades after 888 . How are we to fit this period into our narratives of decline and fall - a period when kings were weak and struggled to assert themselves, but which nonetheless produced at least one, the West Frankish King Charles III the Simple (d.929), a great-great-grandson of Charlemagne, who believed that he had inherited and could restore the imperial glories of the past? ${ }^{7}$ To what extent and in what ways did the kings, queens and princes of Charles's age have to deal with the Carolingian imperial past? Was it regarded as definitely past, or did the empire exert a residual effect constraining the main actors in tenth-century royal politics?

With these questions in mind, the main matter of this article is a reconsideration of four marriages between English princesses and Continental kings and princes from the late 910s to the early 930s. All four brides were daughters of King Edward the Elder (899-924) and half-sisters of King Athelstan (924-39). The first was Eadgifu, sent between 917 and 919 to Charles the Simple, and she was followed by Eadhild, who married Hugh sthe Great‘, Count of Tours, in 926. Then, in 929, as recounted by the English chronicler and aristocrat Æthelweard, >King Athelstan sent another two to Otto [son of the East Frankish King Henry I], the plan being that he should choose as his wife the one who pleased him. He chose Edith ... The other sister he married to a certain king near the Alps..$^{8}$ The story of the marriages was alluded to in several sources from the late tenth and early eleventh centuries on both sides of the Channel, and an author writing for the archbishop of Cologne in the 970s referred

Airlie, Power and its Problems; Airlie, Carolingian Politics.

Airlie, Nearly Men; Booker, Past Convictions.

6 Ferguson, End of Power. Against Ferguson see Mann, Incoherent Empire; Morefield, Empires without Imperialism, 133-168.

7 Koziol, Politics of Memory and Identity, 459-534.

8 Æthelweard, Chronicle, preface, ed. Campbell, 1-2. 
to them as sknown to nearly all.$^{9}$ They were still thought worthy of commemoration in the years around 1120 when the great English historian William of Malmesbury included extensive ruminations on the age of Athelstan in his Deeds of the English Kings. ${ }^{10}$

The marriages have also attracted the attention of modern historians, and are sometimes interpreted as symptomatic of the decline of the Carolingian Empire and the concomitant rise of the English kingdom, whose rulers were inspired by Carolingian precedent and had imperial pretensions of their own. ${ }^{11}$ Athelstan is often seen as a ruler who overtook the declining Carolingians to assume the dominant position in European politics, orchestrating a 'foreign policy which included the marriages of his sisters, interference in the politics of Brittany, Francia and Norway through the nurturing of exiled princes, and the brokerage of a series of alliances against Scandinavian raiders. ${ }^{12} \mathrm{He}$ seems to have regarded himself as a kind of neo-Charlemagne figure, a merger or conqueror of the English kingdoms, and his acquisition of Carolingian royal relics in 926 has been read as a translatio imperii signalling Frankish recognition of his seniority. ${ }^{13}$ This interpretation is supported by a second supposition, namely that Frankish politics in this period was animated by principled attitudes towards Carolingian-ness itself - that people considered themselves either pro- or anti-Carolingian, and acted accordingly. Thus, for example, it has been argued that the architect of the 926 mission to Athelstan, Hugh the Great, was motivated to hand over the relics by anti-Carolingian sentiment. ${ }^{14}$

That such sentiments may have been in play is plausible - if Charles the Simple and his circle could hold a genuine commitment to the Carolingian past, then others might easily have harboured similarly passionate opinions. But the problem is that to explore the Frankish end of the cross-Channel marriages we have to rely on an author who is notoriously silent about the motivations of the people whose deeds he narrates: Flodoard of Rheims, whose Annals provide a detailed and contemporaneous account of West Frankish events between 919 and 966 but almost never deliver commentary or context. ${ }^{15}$ There were clearly unspecified issues at stake which influenced the decisions and actions of the main protagonists but which were so obvious to Flodoard that he did not consider them worth spelling out for a contemporary audience. Conclusions drawn from the text are therefore influenced by one's starting assumptions. In what follows, I retell the story of the marriages starting from the assumption that the actors in Flodoard's story were driven not by lingering devotion or hostility to the aura of the Carolingians, nor by a desire to recognise the new simperium ‘ of Athelstan, but instead by the more immediate matter of the West Frankish royal succession. The succession

Passio S. Ursulae, ed. Levison, 142-157; Leyser, Ottonians and Wessex, 76-79.

10 William of Malmesbury, Gesta regum Anglorum, 2.131-140, ed. Mynors et al., 206-229.

11 Molyneaux, Tenth-Century English Kings.

12 For variously strong and weak versions of this thesis, see for example Leyser, Ottonians and Wessex, 102-103; Sharp, England, Europe and the Celtic World; Ehlers, Sachsen und Angelsachsen, 490-491; Ortenberg, The King from Overseas. Foot, Athelstan, offers a judicious overview.

13 MacLean, Britain, Ireland and Europe, 360. On Athelstan's self-perception see Wood, Stand Strong against the Monsters.

14 Loomis, Holy Relics of Charlemagne and King Athelstan, 440-443; Sharp, England, Europe and the Celtic World, 208.

15 Sot, Un historien et son église; Lecouteux, Le contexte partie 1; Lecouteux, Le contexte partie 2; Roberts, Flodoard. 
was the primary driving force of all early medieval dynastic politics, since anxiety or anticipation about the future of the kingdom was always a pressing political issue. This was never more true than in the West Frankish kingdom of the 920s when, in successive years (922 and 923), one king (Charles the Simple) was deposed and his overthrower (Robert I) was killed. The man who succeeded them, Raoul of Burgundy (923-36), at least enjoyed a relatively lengthy reign, but as early as 924 he had fallen so ill that those around him feared he was dying. ${ }^{16}$ Although he recovered, it was known to all that he was heirless. Given this sequence of events, it is inconceivable that the succession was not at the forefront of the minds of his leading men and neighbours throughout his reign. ${ }^{17}$

The character of the relationships between these men, and the ambitions and anxieties that animated them, are not clearly attested, so we have to read between the lines of Flodoard's account and pay close attention to the timing of events and the sequencing of his narrative. That narrative contains a fairly conspicuous dog that failed to bark. Given the precarious nature of Raoul's grip on the kingship, it is remarkable that neither of the most powerful Frankish magnates, Hugh the Great and Herbert II Count of Vermandois, seem to have made an own bid for the throne themselves - all the more surprising in that Hugh was the son of King Robert I and Herbert was a direct descendant of Charlemagne. Historians writing in the early eleventh century, after Hugh's son Hugh Capet (987-96) had become king, could not believe that the Count of Tours had not sought the throne for himself, and many modern historians have assumed likewise..$^{18}$ But the fact that he did not make any such move in the 920 s or 930 s, despite the huge uncertainty surrounding the kingship and the succession, and held back even on Raoul's death in 936, requires explanation. To understand Hugh's actions we must look carefully at his position within the unfolding politics of the succession. As we shall see, the cross-Channel marriages played an important part in these politics - but less as formal diplomatic alliances than as acts of symbolic communication, conveying nonverbal but pointed messages about the positions of the protagonists with regard to the succession question. ${ }^{19}$

The first of the four marriages was contracted amidst the turbulent later years of Charles the Simple's reign. Although it is hard to make out exactly what was going on due to the absence of any major narrative source covering West Francia between 901 and 919, it is clear that for much of the 910s Charles's court was a difficult place to be, with tensions building around his apparently preferential treatment of an adviser called Hagano who came from Lotharingia, the middle Frankish kingdom which had been annexed by Charles in 911 . This perceived favouritism alienated more established magnates from the heartlands of West Francia who felt they were being treated with less than due respect. ${ }^{20}$ The king's position was

16 Flodoard, Annales, a. 924, ed. Lauer, 23.

17 On Raoul see Lauer, Robert Ier et Raoul de Bourgogne; Felten, Robert I. und Rudolf I. A later source reports that Raoul had a son called Louis who died young: Chronique de l'Abbaye de Saint-Benigne, ed. Bougaud and Garnier, 126; Bouchard, Those of My Blood, 132-133. The son's absence from tenth-century sources suggests he did not feature in contemporary political calculations.

18 Rudolfus Glaber, Historiarum libri quinque, 1.2, ed. France, 14-15; Thietmar, Chronicle, 2.23, ed. Holtzmann, 667. Different views are summarised by Dunbabin, West Francia, 382-383. Koziol, Politics of Memory and Identity, points out he may have been deterred by his father's fate.

19 On symbolic communication see Althoff, Inszenierte Herrschaft.

20 Flodoard, Annales, a. 920, ed. Lauer, 2-5; Koziol, Is Robert I in Hell?; Depreux, Le comte Haganon. 
weakened by the death in 917 of his queen Frederun, herself a Lotharingian, and it is in this context that we would see his acquisition of a new wife.

Eadgifu, a daughter of Edward the Elder by his second wife Ælfflaed, was sent to marry Charles sometime between 917 and 919. Edward's intentions are hard to discern, but it is interesting that the marriage coincided with the high point of his reign: in 918 he was recognised as King in Mercia after the death of his sister and beginning in 920 the >Ar version of the Anglo-Saxon Chronicle claims that he was progressively recognised as the overlord of all the peoples in England (and Britain). ${ }^{21}$ Contracting a marriage alliance with a Carolingian may have seemed a fitting way to underline his growing stature to the people of the Midlands and north of England over whom he was attempting to assert authority. There may have been an element of dynastic tree pruning in the decision about which daughter to send: it was also in 917-18 that Edward ejected Ælfflaed from his court in order to take a third wife, also called Eadgifu, and marrying off the (presumably) eldest daughter of his second wife may have smoothed the transition as the arrival of a new queen prompted the realignment of court factions. ${ }^{22}$ Edward had pre-existing links to parties across the Channel, notably as some kind of honorary lay brother in the community of St. Samson at Dol in Brittany. ${ }^{23}$ In addition, his sister Ælfthryth was married to Count Baldwin II of Flanders. Baldwin's death in September 918 may have been seen as a blow to English influence in northern Francia, which the new marriage would help to shore up. That Edward's own new wife was the scion of a leading Kentish family suggests that he was trying to build his influence in the south-east, the gateway to the Continent, at exactly this time.

For Charles the marriage represented an attempt to defend his increasingly embattled status not simply with a wife who was already royal, but one who might be expected to bear him a son. In this respect there was some immediate success, as the new couple had a son in 920 and gave him a kingly name: Louis. But it was in the same year that, according to Flodoard, ralmost all the counts of Francia gathered at the town of Soissons and abandoned their King Charles. ${ }^{24}$ The choice of place was symbolic. Soissons was where, in 751, the first Carolingian King Pippin had been crowned. Charles was a keen student of early Carolingian history and he played on its resonances to remind his followers that he was a descendant of Pippin and, especially, his son Charlemagne. In 893, Charles had had himself inaugurated as king on the anniversary of Charlemagne's death, the 28th of January. In 920, even as he hoped to ensure the future of the Carolingian dynasty, its past was appropriated by his rivals and directed against him.

The king organised a comeback of sorts, mobilising the support of the archbishop of Rheims and the new East Frankish ruler Henry I, and mounting armed raids against opponents around and beyond the frontier with Lotharingia. ${ }^{25}$ However, Charles's main antagonist Robert of Neustria, whose history of simmering tension with the king went back

21 Anglo-Saxon Chronicle A, a. 920-3, trans. Whitelock, 196-199.

22 Jayakumar, Eadwig and Edgar, shows that the conflicts generated by Edward's remarriage still reverberated a generation later.

23 Whitelock, English Historical Documents, 821-822.

24 Flodoard, Annales, a. 920, ed. Lauer, 2; The Annals of Flodoard, trans. Fanning and Bachrach, Annals, 3.

25 Flodoard, Annales, a. 921, ed. Lauer, 5-6. 
to conflicts between them and their families nearly three decades earlier, managed to build a superior coalition and in 922 had himself recognised as king at Rheims. ${ }^{26}$ His victory did not last long. In the summer of the following year, Charles rallied his forces and attacked Robert at Soissons. In the ensuing battle, Robert was killed: according to a later and no doubt apocryphal account, Charles himself >drove his lance so hard into Robert's sacrilegious mouth that it split his tongue and came out the back of his neck. ${ }^{27}$ Charles nonetheless fled, his support quickly dissolving, and within a few weeks the Frankish magnates had placed on the throne Robert's son-in-law Raoul, the leading magnate in Burgundy. Charles was tricked into a meeting with Count Herbert II of Vermandois, who, carefully shielding his intentions from Raoul, imprisoned him in one of his strongholds. The infant Louis went into exile with his mother to England, where Edward's son Athelstan became king in 924-925. ${ }^{28}$

As a Burgundian, the main problem faced by Raoul was how to gain purchase in the northern heartlands of Francia, where the political landscape was dominated by his brothersin-law Herbert of Vermandois and Hugh the Great. Hugh and Herbert were by far the most powerful magnates in the kingdom, and held lands and honores (offices) that made them de facto equals to or even superiors of the king Hugh in the area between Tours and Paris, and Herbert, in the region east of Paris. ${ }^{29}$ The story of the reign is one of perpetually shifting alliances and conflicts between these three figures, enlivened by a walk-on cast of extras including the King of the East Franks and the counts of Normandy, Aquitaine and Flanders.

The second of the cross-Channel marriages can be read as a feature in this competitive political landscape. In 926 Hugh despatched his embassy to the court of Athelstan and acquired the hand of Eadhild, who was a daughter of Edward by Ælfflaed and therefore a full sister of Eadgifu. Flodoard and Æthelweard give us nothing but the bare bones of this encounter, and for a fuller account we need to turn to William of Malmesbury, who tells us that Hugh's ambassador (the son of Ælfthryth and Baldwin of Flanders, and therefore a cousin of Athelstan) carried rich gifts including a dazzling gold crown and a number of spectacular relics: the sword of Emperor Constantine, Charlemagne's lance, a banner of St. Maurice once carried into battle by Charlemagne, and a piece of the True Cross encased in crystal. ${ }^{30}$ William is a late source, but he did have access to a now-lost book recounting Athelstan's deeds and historians have cautiously accepted his list of the relics given by Hugh to Athelstan, which is circumstantially corroborated by other sources. ${ }^{31}$

Relics exchanged in such contexts were always more than just gifts. The numinous power and rich histories they represented made them, as Julia Smith states, 'political discourse displaced into the realm of cult..$^{32}$ But to which discourse did Hugh's gifts refer? The explicitly

26 Flodoard, Annales, a. 922, ed. Lauer, 10-11.

27 Adalbert, Continuatio, a. 922, ed. Kurze, 156-157.

28 Flodoard, Annales, a. 923, ed. Lauer, 12-19. Nelson, Eadgifu, points out that it is possible that she stayed in Francia for some time.

29 Lauer, Le Règne de Louis IV; Schwager, Graf Heribert II.; Brühl, Ludwig IV.

30 William of Malmesbury, Gesta regum Anglorum, 2.135, ed. Mynors et al., 218-221.

31 Sceptical: Lapidge, Some Latin Poems, 62-71. Optimistic: Wood, Making of King Athelstan's Empire, 265-266; editorial commentary in William of Malmesbury, Gesta regum Anglorum, ed. Mynors et al., vol. 2, 116-118; Leyser, Tenth Century in Byzantine-Western Relationships, 116-117; Smith, Rulers and Relics, 91-95; Foot, Athelstan, $192-198$.

32 Smith, Rulers and Relics, 87. 
royal/imperial connotations of the objects, and particularly their association with Charlemagne, would be hard to mistake even without William's glosses, and the gifts have usually been seen as a recognition on Hugh's part, perhaps on behalf of the Franks, that Athelstan was now the senior European ruler - that there had been a kind of translatio imperii from Francia to Wessex. ${ }^{33}$

As already noted, there is good evidence that Athelstan did fancy himself as a Charlemagne-like quasi-imperial ruler, and the symbolic capital provided by the relics played a part in this. ${ }^{34}$ But pandering to the self-image of the English King does not seem a sufficient motive for the actions of Hugh, embroiled as he was in frantic defence of his territories against Scandinavian settlers in Normandy and struggling to assert his position under the new Burgundian regime in Francia. Even with the prospect of a prestigious bride travelling in the opposite direction, recognition of Athelstan's seniority did not require the surrender of Frankish regalia. A more likely interpretation is that the transfer of these regalian symbols was meant to represent a transmission of Frankish royal power not to Athelstan, but to his nephew and foster son Louis. A hint to this effect may be found in a poem of 927 written to celebrate Athelstan's success in gaining overlordship of Northumbria and Scotland and is addressed to an audience including a squeen (regina) and sprince (clito) residing in the rroyal palacer (palatium regis), probably Winchester. Athelstan had no queen, and his stepmother Eadgifu is conspicuously absent from the sources for his reign..$^{35}$ Could the queen therefore have been Charles the Simple's wife Eadgifu? If so, the sclito - a term implying eligibility for kingship - may well be young Louis rather than, as commonly supposed, the king's half-brother Edwin. ${ }^{36}$

The ostentatious championing of Louis' claims to succeed Raoul was a manoeuvre that was presumably designed above all to enhance Hugh's position within Francia. A speech to this effect, making the case for Louis' succession by lamenting the injustice of his past treatment and highlighting his Carolingian credentials, was put into Hugh's mouth late in the tenth century by the historian Richer of Rheims. ${ }^{37}$ Richer's deployment of direct speech served rhetorical purposes and the details should not be taken literally, but it is interesting that he regarded Hugh's expression of such sentiments as plausible, and that he gave them to the Count of Tours rather than to another character in his story.$^{38}$ Flodoard's contemporary description of Hugh's mission is considerably less florid but also instructive: >Hugh, the son of Robert, married a daughter of Edward, the King of the English, and the sister of the wife of Charles. ${ }^{39}$ For Flodoard, Eadhild's significance lay in the fact that she was Edward the Elder's daughter and Eadgifu's sister, not that she was a half-sister of Athelstan. His frame of reference here was the network of links created in 917-919: he apparently thought the main import of the marriage was that it associated Hugh more closely with Charles and Eadgifu, not with Athelstan.

33 See the works cited in footnotes 12-13 above.

34 See the works cited in footnote 31 above.

35 Stafford, Queen Emma and Queen Edith, 199.

36 Poem and commentary: Lapidge, Some Latin Poems, 83-93, 98; Bobrycki, Breaking and Making Tradition, 24653. Clito: Dumville, Aetheling.

37 Richer, Historiae, 2.2, ed. Hoffmann, 97-98.

38 On rhetoric and plausibility see Lake, Richer of Saint Rémi.

39 Flodoard, Annales, a. 926, ed. Lauer, 36; Annals of Flodoard, trans. Fanning and Bachrach, Annals, 16. 
The context of Hugh's mission supports the argument that its primary purpose was to recognise Louis' status as heir. As the son of a king himself, Hugh was better placed than any other major Frankish magnate to adopt this posture - he had a potential claim of his own to renounce, so the gesture carried an implication of magnanimity, especially given the mutual hatred that had apparently been shared by his father and Louis. ${ }^{40}$ However, we need not imagine that his actions were motivated by a principled attitude to Carolingian legitimacy: leaving Louis to grow up in England, deliberately forgotten, had been a perfectly viable option up to this point. Recognition of the young prince can be understood as a manoeuvre in a much more local competition, for Flodoard drops hints that a contest for access to Carolingian-ness played a part in the relationship between Hugh and the other great magnate of northern Francia, Herbert of Vermandois.

The bitter rivalry between Hugh and Herbert which defined Frankish politics for much of this period did not emerge fully into the open until a spectacular falling out in 929, but there is reason to think that there was tension between them before then. ${ }^{41}$ During 922 they were on different sides of the armed conflict surrounding the kingship, with Herbert initially backing Charles and Hugh siding with his father Robert. Although they seem to have worked together after 923 as the principal brokers of Raoul's influence outside Burgundy, there are clear signs that Herbert, who was older than Hugh and controlled much more land in the politically crucial territory east of the Seine, quickly became the senior partner..$^{42}$ Close reading of Flodoard gives the impression that Herbert was closer to the king and in a position to influence Raoul's interventions in the north while Hugh was occupied containing raids from the Scandinavians settled in Normandy, which abutted his own area of influence in the west. ${ }^{43}$ Herbert's superiority was underlined in 925 when he was given possession of the diocese of Rheims, the ecclesiastical centre of the West Frankish realm, in safe-keeping for his son Hugh, who was appointed archbishop-elect despite being less than 5 years old. Herbert exercised his new status by sending legates to Rome, led by Bishop Abbo of Soissons. ${ }^{44}$ By contrast, 926 is the first year in which Flodoard makes no mention of Hugh the Great playing any role in Frankish politics.

As Geoffrey Koziol has stressed, such men did not take demotion lying down, nor were they in the habit of forgetting past conflicts and insults. ${ }^{45}$ The hints that Herbert was eclipsing the Count of Tours therefore help us understand the timing of Hugh's approach to Athelstan in 926. Openly recognising Louis as a king in waiting was a move that did not just position Hugh as a defender of the wronged prince's rights, and a magnanimous renouncer of his own claims, but also communicated his dissatisfaction with the present king, Raoul. We can also read Hugh's manoeuvre as an attempt to occupy some of the ideological ground that supported Herbert's legitimacy, and to remind the Count of Vermandois that he could

40 Hugh's access to English political circles may have been aided by Breton exiles resident in his stronghold of Paris: Smith, Rulers and Relics, 89. Pro-Louis sentiment elsewhere in the western kingdom is indicated by charters from the Spanish March which refer to Louis as Charles's rightful heir even during Raoul's reign: Felten, Robert I. und Rudolf I., 40.

41 Flodoard, Annales, a. 929, ed. Lauer, 43-45.

42 Flodoard, Annales, a. 922, ed. Lauer, 7-11; Schwager, Graf Heribert II., 115.

43 Flodoard, Annales, a. 924-926, ed. Lauer, 19-36.

44 Flodoard, Annales, a. 925, ed. Lauer, 32-33.

45 Koziol, Politics of Memory and Identity, 553-555. 
not afford to ignore him. Herbert's imprisonment of Charles the Simple had not simply removed him from the game: Widukind of Corvey described Charles's place of captivity as a 'public place (in other words, a place from which power could be exercised). ${ }^{46}$ Even deprived of agency, Charles remained a potential danger to Raoul - the restoration of a Carolingian king was a permanent and visible threat available at Herbert's fingertips. Herbert's position was strengthened by the fact that he himself was a direct descendant of a Carolingian king, Bernard of Italy (d. 818). This was something of which contemporaries were well aware: indeed, the only narrative source to dwell on this connection also dates from the earlier tenth century ${ }^{47}$ Unlike some of the so-called rreguli< (petty-kings) who took power after the death of Charles the Fat in 888, Herbert had a direct claim to Carolingian descent which he chose not to press.

An ancestry that would have conferred only a marginal advantage in the ninth century, when the political landscape was dominated by Carolingians, in the tenth became a source of singular prestige as Carolingian-ness moved into the realm of nostalgia and kings from historically non-royal families took over leadership of the Frankish kingdoms. In this situation, Hugh's approach to Athelstan and Louis is intelligible as an attempt to gain access to an alternative source of Carolingian charisma and thus to play Herbert at his own game: Herbert had Charles, but now Hugh shad Louis. ${ }^{48}$ The success of this manoeuvre may help explain why Herbert was then drawn into alliance with Hugh: in 927 Flodoard reports that the two counts, having fallen out with Raoul, travelled east together to meet Henry I, a confirmed enemy of the West Frankish ruler since seizing Lotharingia from him in $925 .{ }^{49}$

As part of this shift of alliances, in 927 Herbert provoked Raoul further by releasing Charles the Simple into a kind of supervised restoration. ${ }^{50}$ This was a risky move, since the potency of the threat that the ex-king embodied lay precisely in the fact that it was latent. In the following year, after apparently inconclusive negotiations with the pope and Henry I, Herbert renewed his commitment to Raoul and returned Charles to custody. Two subsequent events, reported opaquely by Flodoard, make sense if we assume that the succession was still a current issue in 928 and 929. First, just after the deposed king was once more imprisoned, Raoul scame to Rheims and made peace with Charles, returning Attigny to him and honouring him with gifts.< This performance was part of the sequence of events by which Raoul received the renewed allegiance of Herbert and Hugh, and seems to have been his part of the bargain for the conclusion of peace..$^{51}$ Clearly Raoul cannot have been literally recognising the kingship of the imprisoned Carolingian, but the orchestration of this reconciliation at the royal centre of Rheims, and the investment of Charles with the great Frankish royal palace of Attigny, certainly communicated a public acknowledgement of his royal status. If the

46 Widukind, Rerum Gestarum Saxonicarum, 1.30, ed. Hirsch, 42-43.

47 Regino, Chronicle, a. 818, ed. Kurze, 73. A Soissons manuscript may indicate an awareness of this past in Herbert's own circle: Reimitz, Art of Truth, 98-100.

48 Hugh's marriage to Eadhild restored an indirect family link to the Carolingians to replace the one that had been lost with the death of his first wife - a cousin of Charles the Simple - in 925.

49 Flodoard, Annales, a. 927, ed. Lauer, 37-38. The immediate spark for the falling out was a dispute over the county of Laon.

50 Flodoard, Annales, a. 927, ed. Lauer, 39-40. It is clear from Flodoard's account that Herbert was calling the shots, not Charles.

51 Flodoard, Annales, a. 928, ed. Lauer, 40-43; Richer, Historiae, 1.55, ed. Hoffmann, 88-89. Vienne was also ceded to Herbert's son. 
beneficiary of this symbolic act was not the captive Charles, then it must have been his son. Louis' claims to succeed were not contested after Raoul's death in 936, and the origin of this acceptance must be looked for earlier. The formal recognition by an heirless king of a successor from another family had a very recent precedent: Charles the Simple himself had been recognised as heir by Hugh the Great's uncle King Odo (888-98) as a means of removing his pretext for rebellion and calming the political situation by rendering the future predictable.

Recognition of Charles's line by Raoul would have served the interests of the counts of Vermandois and Tours by confirming their position as guarantors of Louis' claims. In particular, it reinvigorated the status of Hugh, who had played a prominent role in brokering the return of good relations between Herbert and Raoul. ${ }^{52}$ If Hugh's embassy to Louis and Athelstan in 926 had been intended as a means to encroach on the ideological territory occupied by Herbert, the latter's rreleaser of Charles may be evidence that it had worked: in staging his opposition to Raoul through ostentatious allegiance to the Carolingians, and then forcing the king to demonstrate the same allegiance, Herbert not only moved towards Hugh's position but showed himself willing to play the game on terms dictated by the Count of Tours. One way to make sense of these superficially opaque events is therefore to hypothesise that by 928 young Louis' claims had been symbolically recognised by all three parties.

This interpretation also helps explain our second obscure event from Flodoard's Annals: the tipping over of the latent tension between Hugh and Herbert into the on/off open hostility which persisted until the latter's death in 943. The fact of their falling out does not perhaps need much explaining, but the timing does. In Flodoard's telling: >King Charles died at Péronne. A dispute arose between Count Hugh and Count Herbert.....${ }^{53}$ Conjunctions of events in early medieval histories do not simply reveal objective chronological adjacency but can also imply authors' sense of cause and effect: the sequencing of material was neither random nor natural, but an authorial choice. If the political contest of the previous few years had turned on the actors' attempts to advertise their access to various versions of Carolingian legitimacy, then it would hardly be surprising if this new discord was prompted directly by the death of Charles the Simple. Charles was Herbert's trump card, and his demise (on 7 October) meant that Hugh, now positioned as the primary broker of young Louis' prospective succession, was finally able to step out of the shadow of the Count of Vermandois. For most of the next five years it was Herbert who became the outsider in the triangular game of Frankish politics, excluded by a firm alliance between Hugh and Raoul. ${ }^{54}$ There was no clearer sign of this than their joint conquest of Rheims in 931, upon which they installed as archbishop Artold, a local monk who was loyal to Hugh..$^{55}$ Possession of Rheims, and the nomination of his son as archbishop, had been the most obvious symbol of Herbert's political dominance - its removal vividly signified a change of atmosphere.

The focus of the dispute that erupted in 929 was Hugh's acquisition, against Herbert's wishes, of the allegiance of Erluin, Count of Montreuil and Ponthieu. ${ }^{56}$ This was a crucial

52 Flodoard, Annales, a. 927-928, ed. Lauer, 37-43, refers to his role in various negotiations.

53 Flodoard, Annales, a. 929, ed. Lauer, 44.

54 A clear summary of the shifting patterns of alliance in this period is provided by Werner, Westfranken-Frankreich, esp. 233-241.

55 Flodoard, Annales, a. 931, ed. Lauer, 51-52; Richer, Historiae, 1.59-60, ed. Hoffmann, 91-92.

56 Flodoard, Annales, a. 929, ed. Lauer, 43-45. 
area in the maintenance of communications with England (nearby Boulogne was one end of the most important Channel crossing), and we should ask if this sequence of events was also connected in some way with the arrival on the continent, towards the end of 929, of the third and fourth Anglo-Saxon princesses. ${ }^{57}$ The broad outlines of their arrival can be pieced together from allusions in a variety of sources. Æthelweard reported that Henry I asked that Athelstan send two sisters to the Saxons, the idea being that the king's son Otto would choose the one he preferred, and send the second to the court of a scertain king near the Alps. The latter has been conclusively identified as the brother of King Rudolf II of Transjurane Burgundy, another Louis, who was not a king but had been made Count of the Thurgau in the East Frankish kingdom in the wake of a pact concluded between Henry I and Rudolf in $926 .{ }^{58}$ Entries in the libri memoriales (commemoration books) of the great Alemannian monasteries of St. Gall and Reichenau preserve long lists of English and Saxon names associated with the respective courts, and these have been interpreted as footprints of the wedding party as it passed through the region on its way to Burgundy or to the Thurgau. In the Reichenau book, Otto is listed as rex (king) - perhaps an indication that the marriage was taken to have elevated him to full royal status in advance of his father's death, assuming the word was not added later. ${ }^{59}$

Beyond this general outline almost all of the details are hard to pin down, and any reconstruction of agency and chronology has to rely on a series of inferences from the sources. There is reason to be suspicious, for example, of the beauty contest described by Æthelweard, in which Otto was invited to choose the sister he most liked the look of. This kind of bride-show is a literary cliché which derived ultimately from the Book of Esther, and its occasional appearance in early medieval sources probably tells us more about ideological categories used to describe powerful women than about the actual negotiations which preceded royal weddings. ${ }^{60}$ Nor do we know exactly when and where Otto and Edith were married. Our best clue to the timing is the vague comment of Widukind of Corvey that the wedding took place saround the timer that Henry received a victorious army in Quedlinburg after a successful campaign against the Slavs. ${ }^{61}$ This reception is also mentioned in a charter issued at Quedlinburg on 16 September 929, by which Henry confirmed the dower of his wife Mathilda. ${ }^{62}$ The charter formed part of what historians refer to as Henry's Hausordnung (the ordering of his family) and has been interpreted as a response to the arrival of Edith, who may have constituted a threat to Mathilda's position. The entry in the St. Gall liber memorialis, moreover, suggests that the wedding party visited the monastery on 15 October, the eve of the patron's feast, and that they had been given treasure by Athelstan with which to patronise the churches of the kingdom. ${ }^{63}$ The wedding is therefore generally supposed to have taken place at Quedlinburg around the middle of September, with the royal entourage heading off to the south of the kingdom soon after.

59 This has been much debated: Schmid, Neue Quellen zum Verständnis des Adels, 186-202; Althoff, Amicitiae und Pacta, 59, 124-127.

60 Jong, Bride Shows Revisited.

61 Widukind, Rerum Gestarum Saxonicarum, 1.36-37, ed. Hirsch, 51-54.

62 Die Urkunden Konrads I., Heinrich I. und Otto I., ed. Sickel, no. 20.

63 Georgi, Bischof Keonwald von Worcester. 
This is certainly plausible, but there is room for reasonable doubt. The Quedlinburg charter itself does not mention the wedding. The idea of a Hausordnung does not refer to a discrete event but rather a series of measures including an earlier gift to Mathilda in 927 and the marriage of the royal couple's daughter Gerberga to the powerful Lotharingian magnate Giselbert in 928 ${ }^{64}$ These measures can be seen as Henry's attempt to capitalise on a series of spectacular military victories by parlaying the reflected glory into a more permanent reputation for his family as a true royal dynasty. ${ }^{65}$ The arrival of Edith certainly formed part of this process, but need not have been its stimulus. Widukind's reference to the wedding, written at least 30 years later, was not precise and may not have been intended as such. ${ }^{66}$ Another chronicle written about the same time, by someone who was close to Otto and had served in his court for years, placed the marriage in $930 .{ }^{67}$ Although we know that Bishop Cenwald of Worcester, Athelstan's legate, was back in England by April 930, the Swabian memorial lists need not represent the physical presence of the royal couple and their entourage in the monasteries. Such lists represented spiritual alliances, prayer-fraternities rather than registers of attendance, and although they are clearly connected to the mission from England they may do no more than reveal the presence at St. Gall of Cenwald or one of his entourage on pilgrimage. ${ }^{68}$

In other words, it remains possible that the despatch of the two sisters was linked to the series of events we have been describing, and that it may have been prompted by the final illness or death of Charles the Simple. The Continental sources tend to ascribe agency in the matter to Henry I, and there can hardly be any doubt that he was fully involved in the process. But the person who was best placed to broker the unions of 929/30, as indeed that of 926 , was surely Charles's wife Eadgifu. ${ }^{69}$ No contemporary author states this explicitly, and she is virtually invisible in the sources before 936. But not only was she a sister of Athelstan and of all the women involved, she also had several years' experience at the court of her husband, where she would have become known to all the leading figures in post-Carolingian politics. She had certainly been a significant player at the time of Charles's deposition in 923, to judge from the comment of the historian Folcuin, Abbot of Lobbes (965-90), that she too suffered many persecutions at that time. ${ }^{70} \mathrm{~A}$ hint that she remained on the scene is provided by the so-called Gandersheim Gospels, a ninth-century book from Metz that seemingly passed from the West Frankish court to the east during one of the exchanges of this period. The last leaf contains a note added in an English hand: 'Eadgifu the queen - Athelstan King of the Anglo-Saxons and Mercians`. Eadgifu's name is given prominence here through the ordering and through the fact that it is accompanied by a cross, unlike Athelstan's. Moreover, the book is not known to have been in England, so a Continental context for the inscription is likely. These considerations support the identification with Charles's wife rather than Athelstan's step-mother, and the events of 929-30 provide a likely context. ${ }^{71}$ From Eadgifu's point of

64 See the discussion appended to Die Urkunden Konrads I., Heinrich I. und Otto I., ed. Sickel, no. 20.

65 On the Hausordnung see Becher, Loyalität oder Opposition?

66 Robbie, Can Silence Speak Volumes?

67 Adalbert, Continuatio, 930, ed. Kurze, 158.

68 Georgi, Bischof Keonwald von Worcester. On the methodological point: Butz, Eternal Amicitia?

69 Nelson, Eadgifu.

70 Folcuin, Gesta Abbatum Sithiensium, c. 101, ed. Holder-Egger, 625-626.

71 Nelson, Eadgifu; cf. Keynes, King Athelstan's Books, 189-93; Foot, Athelstan, 58. The other Eadgifu was not prominent in Athelstan's reign: See the works cited in footnotes 35 above. 
view, the need to provide a support network for the potential arrival in Francia of her young son was paramount. In 929, this need became suddenly pressing not just because of the death of Charles, but also that of Ælfthryth of Flanders, Eadgifu's aunt.

If, as I have argued, the status of Louis' claim to the West Frankish throne was a defining political issue of the later 920s, and if Hugh the Great's mission of 926 was the ultimate reference point for the marriages of 929, we should finally ask what the fate of Charles the Simple might have meant from an East Frankish perspective. There are glimmers of evidence hinting that a broader coalition was backing Louis even before the arrival of Edith and her sister. ${ }^{72}$ We have already noted the royal character of the gifts taken to Athelstan by Hugh, and in particular their associations with Charlemagne. Among them were two that probably had a provenance further east: the banner of St. Maurice points clearly to Rudolf II of Transjurane Burgundy, under whose patronage that martyr's cult was especially fostered, and the crystallised fragment of the Cross, which is a relic known to have been associated with the East Frankish kings in the ninth century, may have come from Henry I. ${ }^{73}$ Rudolf and Henry sealed a formal pact of friendship towards the end of 926, as part of which the Burgundian King handed over to the Saxon a Holy Lance and received in return the East Frankish county of Thurgau, which, as we have seen, was placed in the hands of his brother Louis. Rudolf's brother and Henry's son were the recipients of Anglo-Saxon royal brides three years later, and given that Hugh the Great travelled to England with royal gifts which may have originated at their courts, we can speculate that they had backed Hugh's endorsement of King Charles's young son in 926. For Henry in particular this would have been a potentially fruitful and low-risk strategy. Defence of the absent Louis may have given him a kind of legitimacy for his annexation in 925 of Lotharingia, to which he had no historical claim, and which also gave him a motive to oppose Raoul. Indeed, when Hugh and Herbert cemented their opposition to Raoul by making a pact with Henry in 928, his main opponent in Lotharingia was none other than the brother of the West Frankish king. ${ }^{74}$ It is also interesting that Widukind claims, amidst reports of events that took place in the middle of the 920s, that Charles the Simple sent Henry, as a symbol of their mutual love, a relic of St. Denis from his captivity (no doubt a reference to the treaty they had concluded at Bonn in 921). ${ }^{75}$ The cult of St. Denis was, more than any other, associated with the legitimate kingship of West Francia. Widukind's account is not to be taken at face value, but it points to a sense in the East Frankish kingdom that Henry had been sympathetic to the plight of Charles, and therefore perhaps the cause of his son, at about the same time that Hugh the Great sent his mission to England. ${ }^{76}$

Much of this reasoning is hypothetical and depends on inferring motives from the bald descriptions of events found in Flodoard's Annals - but no more so than any other attempt to reconstruct the political circumstances of the 920s and 930s. Assuming that the protean matter of the royal succession was the primary issue around which contemporary politics

For different reconstructions of the following, cf. MacLean, Britain, Ireland and Europe, 359-361; Smith, Rulers and Relics, 91-4.

73 On the cult of the Cross at the East Frankish court see Goldberg, "More Devoted to the Equipment of Battle«.

Flodoard, Annales, a. 928, ed. Lauer, 40-43. ing early eleventh century priorities. The East Franks do seem to have acquired relics of St. Denis at some point in the middle decades of the tenth century: Koziol, Charles the Simple. 
revolved seems to me to make the pieces fit together more coherently than the alternatives. This hypothesis helps us make sense of the timing of the cross-Channel marriages, and helps explain why Louis IV was able to return as king in 936 apparently unopposed. I do not wish to suggest that this outcome was inevitable, but that it came about through the unfolding of events and accumulation of prior claims and commitments. If latent support for Louis ever hardened into something approaching a formal covenant, then it may have been at the two large assemblies arranged by Raoul in 935 after the death of his queen Emma and only months before his own, at which he, Herbert, Hugh, Henry I, Rudolf II and sthe magnates of the kingdom r reached agreement on matters unspecified by Flodoard. ${ }^{77}$ The annalist's blasé description of the new king's arrival in 936, read in isolation, might easily be read as testimony to the unblemished aura of Carolingian blood and the long reach of Louis' patron Athelstan. In reality, as the foregoing suggests, Louis and Athelstan had loomed over Raoul's reign not as agents but as absent presences - Frankish loyalties were dictated not by interventions from outside but by evolving tensions between the Frankish princes themselves.

The competitions which consumed these men and women (for the West Frankish crown, for seniority among the Frankish magnates, for control of territory in the middle portion of the old empire) were zero-sum games whose contours were defined by shifting patterns of alliances and friendships, made and then broken, as they sought to play their rivals against each other. The main actors were animated neither by a passive sense of obeisance to Athelstan nor by the principled pro- or anti-Carolingian positions which historians have sometimes ascribed to them. The idea of Carolingian kingship was at stake not as a static focus for allegiance or opposition, but as a discourse which could be manipulated into the service of all sorts of narrower political agendas. It was a position which all the main contemporary players competed to appropriate, each with different and shifting goals in mind.

The potency of this discourse in the 920s was not simply due to the posthumous aura of Charlemagne or to a sense that the ninth-century empire could somehow still be a going concern. Its roots were surely shallower: a consequence of the fact that Charles the Simple had himself instrumentalised Carolingian-ness as the central idiom of Frankish royal legitimacy. It had therefore become an unavoidable aspect of contemporary politics. Despite the reputation of this period for unregulated and violent political conduct, the Franks were not in the habit of deposing their kings, and when they did they were haunted by doubt and recrimination. ${ }^{78}$ Charles and his son Louis, imprisoned and exiled, were not just Carolingians but also living kings, and as such could not be simply forgotten. No debate about the West Frankish kingship and the succession to Raoul could have ignored them. Keeping Charles and Louis in the game, even as they were out of it, thus became a central strategy of the various would-be kings and kingmakers jostling for position. In this context, the marriages of the Anglo-Saxon princesses seem less like stately diplomatic exchanges used to calibrate the prestige of different rulers or seal formal alliances against the Vikings than acts of symbolic communication which articulated and publicised the complex and shifting game of one-upmanship in which the protagonists were engaged.

77 Flodoard, Annales, s. 935, ed. Lauer, 60-62.

78 De Jong, Penitential State; Koziol, Is Robert I in Hell? 
What we see in these events, then, is not per se a vestigial allegiance to the idea of a Carolingian Empire, nor a desire to perform the decline of the empire at the feet of the rising King of Wessex, but an instrumentalisation of Carolingian-ness in a context in which it had had become a resource rather than a norm. ${ }^{79}$ The version of Carolingian-ness we have been considering is therefore best seen as a phenomenon specifically of the post-empire era rather than as a final chapter in a longer story of decay - though that preference is, ultimately, a matter of taste. Whichever we prefer, the story did not of course end in 936, but it did begin to turn in a new direction. The cross-Channel marriages and the political networks they established were an important but relatively short-lived phenomenon. ${ }^{80}$ Eadhild died in or before 937, Edith in 946 and Eadgifu in or after 951. They were not replaced: as rare as cross-Channel royal marriages had been in the ninth century, they were even scarcer in the late tenth, and for a sequel we need to wait for the wedding of Æthelred II (the Unready) to Emma of Normandy in 1002. In the meantime, West Frankish potentates began to seek brides from the east rather than the north. When Hugh the Great remarried in 937, it was to Hadwig, a daughter of Henry I. Two years later, Louis IV married her sister Gerberga. The political relationships of the tenth-century kingdoms, in which royal women continued to play a vital role, were defined in the next generation above all by these women and their connections with the court of their brother Otto I. England, even under rulers with more power and prestige than Athelstan, faded from their calculations. And although Louis IV continued to insist upon his Carolingian identity and was able to pass his throne onto his son Lothar (954-86), under the latter royal self-representation gradually left behind the familiar idioms of the ninth century and began to emulate new forms pioneered by Otto. ${ }^{81}$ But this is the beginning of yet another story - of how tenth-century Europe became the Ottonian Europe, and of how the Carolingian past moved ever more emphatically into the past. ${ }^{82}$

79 My argument here follows and supports that of Airlie, Carolingian Politics.

80 MacLean, Making a Difference.

81 Keller, Zu den Siegeln der Karolinger.

82 I am grateful to Charles Insley, Jinty Nelson, Edward Roberts and Pauline Stafford for comments on earlier versions of this article. 


\section{References}

Adalbert, Continuatio, ed. Friedrich Kurze, Reginonis abbatis prumiensis Chronicon, cum continuatione treverensi, MGH Scriptores rerum Germanicarum (Hanover, 1890).

Æthelweard, Chronicle, ed. Alistair Campbell, The Chronicle of Æthelweard (London, 1962).

Airlie, Stuart, Carolingian Politics, forthcoming.

Airlie, Stuart, Power and its Problems in Carolingian Europe (Farnham, 2012).

Airlie, Stuart, The Nearly Men: Boso of Vienne and Arnulf of Bavaria, in: Stuart Airlie, Power and its Problems, 1-19.

Althoff, Gerd, Amicitiae und Pacta. Bündnis, Einung, Politik und Gebetsgedenken im beginnenden 10. Jahrhundert (Hanover, 1992).

Althoff, Gerd, Inszenierte Herrschaft: Geschichtsschreibung und politisches Handeln im Mittelalter (Darmstadt, 2003).

Anglo-Saxon Chronicle, trans. Dorothy Whitelock, English Historical Documents I, c. 500-1042 (London, 1955).

Becher, Matthias, Loyalität oder Opposition? Die Sachsen und die Thronfolge im Ostfrankenreich (929-939), in: Caspar Ehlers, Jörg Jarnut and Matthias Wemhoff (eds.), Deutsche Königspfalzen 7 (Göttingen, 2007) 69-86.

Bobrycki, Shane, Breaking and Making Tradition: Aethelstan, Abd al-Rahman III and their Panegyrists, in: Lynette Mitchell and Charles Melville (eds.), Every Inch a King: Comparative Studies on Kings and Kingship in the Ancient and Medieval Worlds (Leiden and Boston, 2013) 245-267.

Booker, Courtney, Past Convictions: the Penance of Louis the Pious and the Decline of the Carolingians (Philadelphia, 2009).

Bouchard, Constance, Those of My Blood: Constructing Noble Families in Medieval Francia (Philadelphia, 2001).

Brühl, Carlrichard, Ludwig IV. (»der Überseeische«) 936-954), in: Joachim Ehlers, Heribert Müller and Bernd Schneidmüller (eds.), Die französischen Könige des Mittelalters. Von Odo bis Karl VIII. (888-1498) (Munich, 1996) 42-54.

Burbank, Jane and Cooper, Frederick, Empires in World History (Princeton and Oxford, 2010).

Butz, Eva-Maria, Eternal Amicitia? Social and Political Relationships in the Early Medieval Libri Memoriales, in: Katariina Mustakallio and Christian Krötzl (eds.), De amicitia. Friendship and Social Networks in Antiquity and the Middle Ages (Rome, 2009) 155-172.

Chronique de l'Abbaye de Saint-Benigne de Dijon, ed. Émile Bougaud and Joseph Garnier (Dijon, 1875).

Depreux, Philippe, Le comte Haganon, favori de Charles le Simple, et l'aristocratie d'entre Loire et Rhin, in: Michèle Gaillard, Michel Margue, Alain Dierkens and Hérold Pettiau, De la mer du Nord à la Méditerranée. Francia Media, une région au coeur de l'Europe (c. 840c. 1050) (Luxembourg, 2011) 381-393.

Die Urkunden Konrad I., Heinrich I. und Otto I., ed. Theordor Sickel, MGH Diplomata regum et imperatorum Germaniae (Hanover, 1879-1884).

Dumville, David, The Aetheling: a Study in Anglo-Saxon Constitutional History, Anglo-Saxon England 8 (1979) 1-33.

Dunbabin, Jean, West Francia: The Kingdom, in: Timothy Reuter (ed.), The New Cambridge Medieval History 3, c. 90o-c. 1024 (Cambridge, 1999) 372-397. 
Ehlers, Joachim, Sachsen und Angelsachsen im 10. Jahrhundert, in: Matthias Puhle (ed.), Otto der Grosse. Magdeburg und Europa 1 (Mainz, 2001) 489-502.

Fanning, Steven and Bachrach, Bernard, The Annals of Flodoard of Reims, 919-966 (Peterborough, 2004).

Felten, Franz, Robert I. 922/3 und Rudolf I. 923-936, in: Joachim Ehlers, Heribert Müller and Bernd Schneidmüller (eds.), Die französischen Könige des Mittelalters. Von Odo bis Karl VIII. (888-1498) (Munich, 1996) 36-45.

Ferguson, Niall, The End of Power. Retrieved on 18 August 2015: http://www.niallferguson. com/journalism/politics/the-end-of-power.

Flodoard, Annales, ed. Philippe Lauer (Paris, 1905).

Folcuin, Gesta Abbatum Sithiensium, ed. Oswald Holder-Egger, MGH Scriptores 13 (Hanover, 1881) 607-635.

Foot, Sarah, Athelstan: the First King of England (Yale, 2011).

Georgi, Wolfgang, Bischof Keonwald von Worcester und die Heirat Ottos I. mit Egitha im Jahre 929, Historisches Jahrbuch 115 (1995) 1-40.

Goldberg, Eric, »More Devoted to the Equipment of Battle Than the Splendor of Banquets«: Frontier Kingship, Martial Ritual, and Early Knighthood at the Court of Louis the German, Viator 30 (1999) 41-78.

Grierson, Philip, The Relations between England and Flanders before the Norman Conquest, Transactions of the Royal Historical Society 23 (1941) 71-112.

Hlawitschka, Eduard, Die verwandtschaftlichen Verbindungen zwischen dem hochburgundischen und dem niederburgundischen Königshaus. Zugleich ein Beitrag zur Geschichte Burgunds in der 1. Hälfte des 10. Jahrhunderts, in: Waldemar Schlögl and Peter Herde (eds.), Grundwissenschaften und Geschichte. Festschrift für Peter Acht (Kallmünz, 1976) 28-57.

Jayakumar, Shahshi, Eadwig and Edgar: Politics, Propaganda, Faction, in: Donald Scragg (ed.), Edgar, King of the English, 959-975 (Woodbridge, 2008) 83-103.

Jong, Mayke de, Bride Shows Revisited: Praise, Slander and Exegesis in the Reign of the Empress Judith, in: Leslie Brubaker and Julia M. H. Smith (eds.), Gender in the Early Medieval World. East and West, 300-900 (Cambridge, 2004) 257-277.

Jong, Mayke de, The Penitential State. Authority and Atonement in the Age of Louis the Pious, 814-840 (Cambridge, 2009).

Keller, Hagen, Zu den Siegeln der Karolinger und der Ottonen. Urkunden als >Hoheitszeichen in der Kommunikation des Königs mit seinem Getreuen, Frühmittelalterliche Studien 32 (1998) 400-441.

Keynes, Simon, King Athelstan's Books, in: M. Lapidge and H. Gneuss (eds.), Learning and Literature in Anglo-Saxon England (Cambridge, 1985) 143-201.

Koziol, Geoffrey, Charles the Simple, Robert of Neustria, and the vexilla of Saint-Denis, Early Medieval Europe 14 (2006) 355-390.

Koziol, Geoffrey, Is Robert I in Hell? The Diploma for Saint-Denis and the Mind of a Usurper (January 25, 923), Early Medieval Europe 14 (2006) 233-267.

Koziol, Geoffrey, The Politics of Memory and Identity in Carolingian Royal Diplomas: The West Frankish Kingdom (841-987) (Turnhout, 2012).

Lake, Justin, Richer of Saint Rémi (Washington, 2013).

Lapidge, Michael, Some Latin Poems as Evidence for the Reign of Athelstan, Anglo-Saxon England 9 (1981) 61-98.

Lauer, Philippe, Le Règne de Louis IV d'Outre-Mer (Paris, 1900).

Lauer, Philippe, Robert Ier et Raoul de Bourgogne, rois de France (923-36) (Paris, 1910). 
Lecouteux, Stéphane, Le contexte de rédaction des Annales de Flodoard de Reims (919-966). Partie 1: une relecture critique du début des Annales à la lumière de travaux récents, $L e$ Moyen Âge 116 (2010) 51-121.

Lecouteux, Stéphane, Le contexte de rédaction des Annales de Flodoard de Reims (919-966). Partie 2: présentation des résultats de la relecture critique du début des Annales, Le Moyen Âge 116 (2010) 283-317.

Leyser, Karl, The Ottonians and Wessex, in: Karl Leyser, Communications and Power in Medieval Europe I, ed. Timothy Reuter (London and Rio Grande, 1994) 73-104.

Leyser, Karl, The Tenth Century in Byzantine-Western Relationships, in: Karl Leyser, Medieval Germany and its Neighbours 90o-1250 (London, 1982) 103-37.

Loomis, Laura H., The Holy Relics of Charlemagne and King Athelstan: The Lances of Longinus and St. Mauricius, Speculum 25 (1950) 437-456.

MacLean, Simon, Britain, Ireland and Europe, c. 900-c. 1100, in: Pauline Stafford (ed.), A Companion to the Early Middle Ages: Britain and Ireland, c. 500-110o (London, 2009) 358-375.

MacLean, Simon, Making a Difference in Tenth-Century Politics: King Athelstan's Sisters and Frankish Queenship, in: Paul Fouracre and David Ganz (eds.), Frankland. The Franks and the World of Early Medieval Europe: Essays in Honour of Dame Jinty Nelson (Manchester, 2008) 167-190.

Mann, Michael, Incoherent Empire (London and New York, 2003).

Molyneaux, George, Why Were Some Tenth-Century English Kings Presented As Rulers of Britain?, Transactions of the Royal Historical Society 21 (2011) 59-91.

Morefield, Jeanne, Empires without Imperialism: Anglo-American Decline and the Politics of Deflection (Oxford and New York, 2014).

Nelson, Janet, Eadgifu, in: Colin H. C. G. Matthew and Brian Harrison (eds.), Oxford Dictionary of National Biography (Oxford, 2004).

Ortenberg, Veronica, The King from Overseas: Why Did Athelstan Matter in Tenth-Century Continental Affairs?, in: David Rollason, Conrad Leyser and Hannah Williams (eds.), England and the Continent in the Tenth Century (Turnhout, 2011) 211-236.

Passio S. Ursulae, ed. Wilhelm Levison, Das Werden der Ursula-Legende, Bonner Jahrbücher 132 (1928) 1-164.

Regino, Chronicle, ed. Friedrich Kurze, Reginonis abbatis prumiensis Chronicon, cum continuatione treverensi, MGH Scriptores rerum Germanicarum (Hanover, 1890).

Reimitz, Helmut, The Art of Truth. Historiography and Identity in the Frankish World, in: Richard Corradini, Rob Meens, Christina Pössl and Philip Shaw (eds.), Texts and Identities in the Early Middle Ages (Vienna, 2006) 87-104.

Reynolds, Susan, Empires: A Problem of Comparative History, Historical Research 79 (2006) 151-165.

Richer, Historiae, ed. Hartmut Hoffmann, MGH Scriptores 38 (Hanover, 2000).

Robbie, Steven, Can Silence Speak Volumes? Widukind's Res Gestae Saxonicae and the Coronation of Otto I Reconsidered, Early Medieval Europe 20 (2012) 333-362.

Roberts, Edward, Flodoard, the Will of St. Remigius and the See of Reims in the Tenth Century, Early Medieval Europe 22 (2014) 201-230.

Rodulfus Glaber, Historiarum libri quinque, ed. John France (Oxford, 1989).

Schmid, Karl, Neue Quellen zum Verständnis des Adels im 10. Jahrhundert, Zeitschrift für die Geschichte des Oberrheins 69 (1960) 185-232. 
Schwager, Helmut, Graf Heribert II. von Soissons, Omois, Meaux, Madrie sowie Vermandois (900/o6-43) und die Francia (Nord-Frankreich) in der 1. Hälfte des 10. Jahrhunderts (Kallmünz, 1994).

Sharp, Sheila, England, Europe and the Celtic World: King Athelstan's Foreign Policy, Bulletin of the John Rylands University Library of Manchester 79 (1997) 197-220.

Smith, Julia, Rulers and Relics, c. 750-c. 950: Treasure on Earth, Treasure in Heaven, Past and Present Supplement 5 (2010) 73-96.

Sot, Michel, Un historien et son église au X siècle: Flodoard de Reims (Paris, 1993).

Stafford, Pauline, Queen Emma and Queen Edith: Queenship and Women's Power in Eleventh-Century England (Oxford, 1997).

Thietmar, Chronicle, ed. Robert Holtzmann, MGH Scriptores rerum Germanicarum Nova Series 9 (Berlin, 1935).

Werner, Karl F., Westfranken-Frankreich unter den Spätkarolingern und frühen Kapetingern (888-1060), in: Karl F. Werner, Vom Frankenreich zur Entfaltung Deutschlands und Frankreichs (Sigmaringen, 1984) 225-277.

West, Charles, Reframing the Feudal Revolution: Political and Social Transformation Between Marne and Moselle (c. 80o-c. 1100) (Cambridge, 2013).

Whitelock, Dorothy, English Historical Documents I 500-1042 (London, 1955).

Widukind, Rerum Gestarum Saxonicarum Libri Tres, ed. Paul Hirsch, MGH Scriptores rerum Germanicarum (Hanover, 1935).

William of Malmesbury, Gesta regum Anglorum, ed. and trans. by Roger A. B. Mynors, Rodney M. Thomson and Michael Winterbottom (Oxford, 1998-1999).

Wood, Michael, Stand Strong against the Monsters: Kingship and Learning in the Empire of Athelstan, in: Janet Nelson and Patrick Wormald (eds.), Lay Intellectuals in the Carolingian World (Cambridge, 2007) 192-217.

Wood, Michael, The Making of King Athelstan's Empire: an English Charlemagne?, in: Patrick Wormald, Donald Bullough and Roger Collins (eds.), Ideal and Reality in Frankish and Anglo-Saxon Society (Oxford, 1983) 250-272. 